\title{
Tissue Expediter
}

National Cancer Institute

\section{Source}

National Cancer Institute. Tissue Expediter. NCI Thesaurus. Code C19923.

An $\mathrm{NCl}$ scientist whose role is to identify sources of human tissue specimens and help researchers locate the tissue and related data they need. (Bypass Budget) 